認定医症例報告

義歯による発音障害を主訴とした高度な顎堤吸収を伴う無歯顎症例

小平 順可

\title{
An Edentulous Case with Articulation Disorder and Severe Bone Resorption
}

Kodaira Yorika

抄 録

症例の概要：71 歳の男性で，上下顎総義歯の維持不良による発音障害を主訴に来院した，顎堤は，上下顎 ともに高度な吸収を認めた。義歯は床縁が短く維持も不良で, 機能時に離脱が認められた。装着していた 義歯を治療用義歯として, 義歯の維持と顎位の改善を図ることとし, これらが得られたことを確認した上で 新義歯を作製した.

考察：治療前後の評価より, 発音機能の回復が得られたと考える. 患者が新義歯に順応し舌の運動範囲が 拡大したことが推測される。これは，新義歯に適切な舌房形態を与えることができたためと考える.

結論：維持・安定が図られ, 発音機能の改善を考慮した新義歯は, 機能時に離脱を認めず, 発音が明瞭となった.

和文キーワード

総義歯, 発音障害, 口蓋部形態, パラトグラム, 維持

\section{ABSTRACT}

Patient: A 71-year-old man complained of articulation disorder caused by poor retention of the upper and lower complete dentures. Both maxillary and mandibular residual ridges showed severe resorption. The dentures had short base borders and poor retentions, and were sway with mandibular functional movement. First, I planned to improve the retention and mandibular position of his dentures by repairing his dentures. When I confirmed to make a good retention and an appropriate mandibular position, I started to make new dentures, and then set them.

Discussion: Evaluation before and after treatment showed recovery of articular function. The new denture, which has suitable tongue space, made the tongue movement area during speaking wider. This might result from the patient acclimatizing to a new condition.

Conclusion: New dentures showing stable retention and good articular function were not sway during functioning or articulation, and the patients articulation became clear.

\section{Key words}

complete denture, articulation disorder, palatal morphology, palatogram, retention

\section{東京歯科大学有床義歯補綴学講座}

Department of Removable Prosthodontics and Gerodontology, Tokyo Dental College

受付： 2007 年 9 月 20 日/受理：2008 年 5 月 3 日

Received on September 20, 2007/Accepted on May 3, 2008 


\section{I. 緒言}

高度な顎堤吸収を伴う無歯顎症例は, 顎堤の形態 から十分な義歯の維持・安定を図ることが困難な場 合が多い1)。また，これに伴い患者は発音時の義歯の 不具合を訴えることがある。したがってこのような症 例においては，咀嚼機能のみならず，発音機能も十分 に考慮に入れた義歯を製作しなければならない.

今回，発音障害を主訴とした高度な顎堤吸収を伴 う無歯顎症例に対し, 維持および安定, 口蓋部形態を 考慮した形態の義歯を製作したところ，発音機能が回 復し，機能時に離脱を認めず，発音が明瞭となった 症例を経験したので報告する.

\section{II. 症例の概要}

患者は, 2001 年 6 月に来院した初診時年齢 71 歳の 男性である. 12 年前に無歯顎となり， 4 年前に 2 個 目の総義歯を製作して現在に至る。発音時に下顎義 歯が浮き上がるため, 新義歯製作を希望して近医を 受診したところ，顎堤吸収が著しく義歯の製作が困 難とのことで当院に紹介となった.

顎堤は，上下顎ともに高度な吸収を認め，上顎前 歯部の顎堤はフラビーガムを有し，下顎右側臼歯部 の顎堤はすり鉢状の形態を呈していた。装着してい た義歯は，床縁が短く維持も不良で，機能時に離脱 が認められた，右側臼歯部の人工歯の咬耗が著しく 咬合平面が傾斜していた。発音時，上顎義歯に離脱 は認めないものの，下顎義歯は右側臼歯部の排列が 舌側寄りであったため，舌の動きによって離脱が認 められた（図1)。顔面計測にて，下顎安静位と中心咬 合位の鼻下点ーオトガイ底間距離を計測したところ， 下顎安静位で $65 \mathrm{~mm}$ ，中心咬合位で $50 \mathrm{~mm}$, 安静空 隙量は, $15 \mathrm{~mm}$ であった。初診時の顔貌写真を図 2 に示す。CTにより確認したところ骨吸収は，上顎前 歯部は梨状口下縁付近，下顎はオトガイ孔部付近ま で達していた (図 3). 以上のことから，義歯の維持 不良による発音障害および低位咬合と診断した。な お，初診時の患者満足度は Face scale ${ }^{2)}$ で，12/20 で あった

\section{III. 治療内容と経過}

使用中の義歯の咬合平面の修正，床縁の延長，咬 合挙上を伴う碩位の改善およびティッシュコンディ
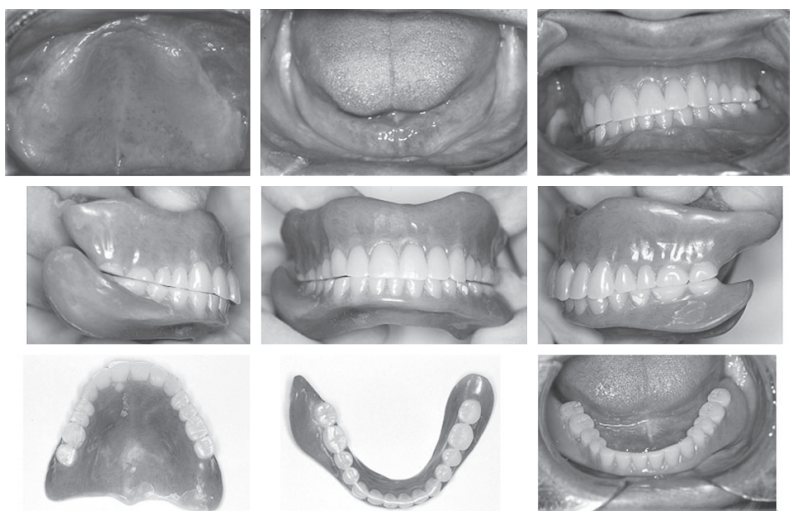

図 1 Intraoral views and dentures at the first examination 初診時の口腔内および義歯の写真

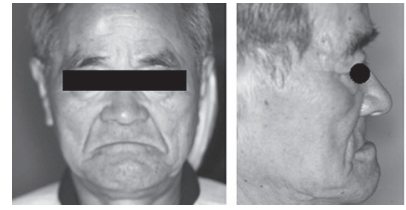

義歯未装着時

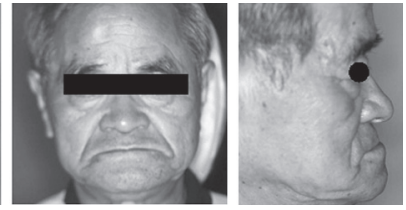

義歯装着時
図 2 Facial view at the first examination Before denture wearing After denture wearing 初診時の顔貌写真 義歯未装着時 義歯装着時

ショニングを行って治療用義歯とすることにした，そ してその後に，新義歯を製作することとした。まず使 用中の義歯の咬合平面を修正し，下顎臼歯部の排列 位置の修正，床縁の延長を行った後，ティッシュコン ディショニングおよび咬合挙上を行った（図 4)。咬合 挙上は, 1 回の挙上量を $3 \mathrm{~mm}$ 程度とし，2 週間間隔 で 4 回に分けて挙上した(図 5)。治療用義歯の維持・ 安定が得られたことで, 発音, 咀嚼時の義歯の離脱 はなくなり，発音障害はほぼ解消されたが，ラ音の発 音は不明瞭であった。これに対して, 新義歯製作時 に静的パラトグラムの採得を行うこととした．主訴が ほぼ解消した時点 (治療用義歯の使用 13 週)の Face scale は，8/20であった.

ろう義歯試適時に静的パラトグラムの採得を行っ た. カ，サ，夕音は少ない修正で標準型を得ることが できたが，ラ音の獲得には，口蓋前方部に多量に厚み を加える必要があった（図 6). ラ音の発音が獲得でき ていた状態のパラトグラムは，標準型より口蓋前方 部の舌の接触がやや後方に位置した形態であった（図 7)。また，新義歯は安定を得るために，顎堤の斜面 となる部位には人工歯を排列せず第 1 大臼歯までの 


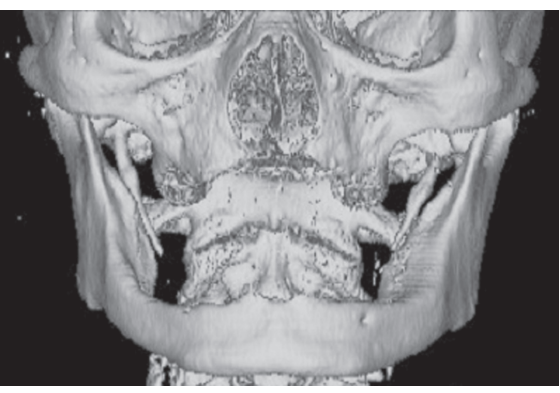

図 3 A CT image at the first examination 初診時の CT 画像

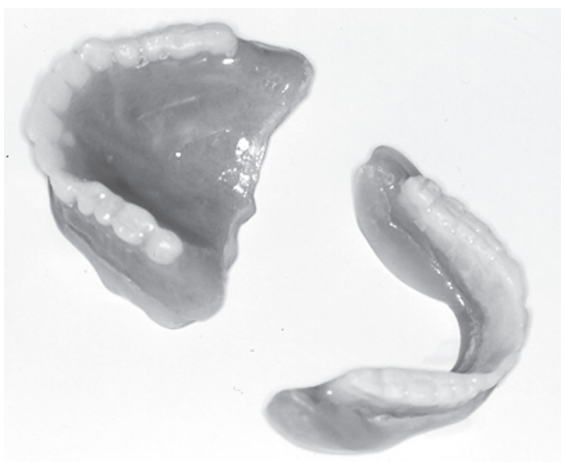

図 4 Treatment denture after adjustment 調整が終了した治療用義歯

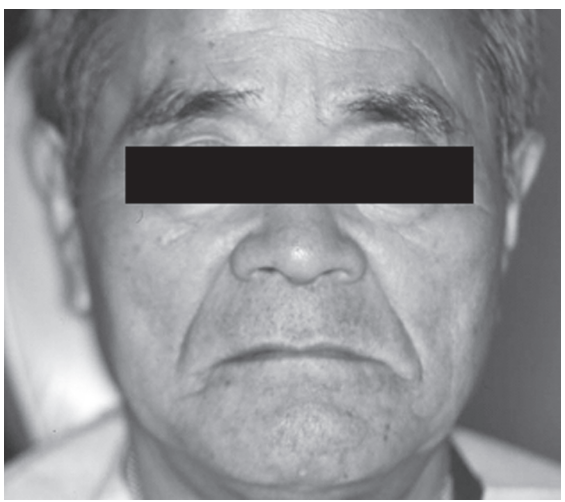

図 5 Facial view after vertical dimension increase 咬合挙上後の顔貌

排列とした（図 8).

新義歯装着直後に, 義歯の安定が崩れ咀嚼時の床 下粘膜の疼痛を訴えた。右側の顎堤は左側に比べて 平坦かつ煩舌的な斜面を呈し顎堤の条件が悪いた め, 右側での咀嚼時に義歯の安定が崩れ疼痛の原因 になっていることが伺えた，そこで，咬合支持は左側 に求めることが義歯の安定につながると考え，可能な

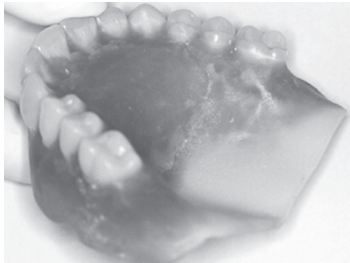

ろう義歯

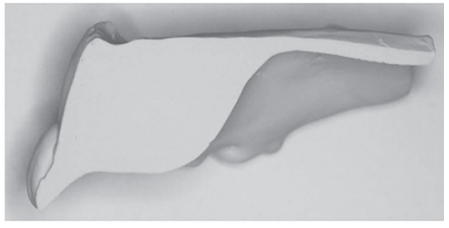

ろう義歯のデュープ模型
図 6 Palatal morphology of wax denture after reform A wax denture

A dupe model of the wax denture 修正した口蓋部形態

ろう義歯

ろう義歯のデュープ模型の矢状断面

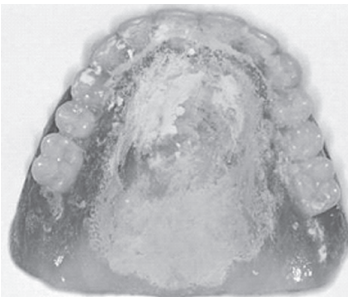

修正前の口蓋部形態

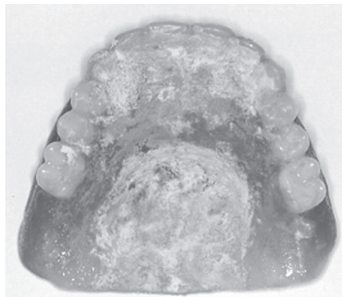

修正後の口蓋部形態
図 7 A palatogram (“ra” sound) at try-in Before reform of palatal morphology of denture After reform of palatal morphology of denture 試適時のパラトグラム（ラ音） 修正前の口蓋部形態 修正後の口盍部形態

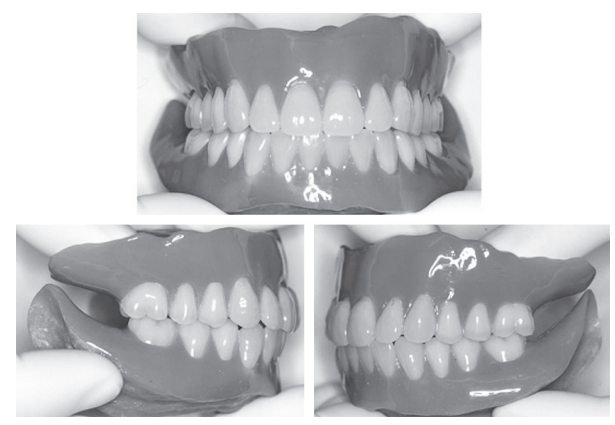

図 8 The final prosthesis 最終補綴装置

範囲で，咀嚼時の支持を左側に求めることを指導し た (図 9 )。 その後, 発音機能が回復した新義歯は, 発 音時に離脱を認めず，発音が明瞭となった。また， 義歯の片側性均衡も成り立ち咀嚼運動も問題なく行 うことができた．新義歯調整後（新義歯装着 6 週）の Face scale は，4/20 となり経過観察に入った.

最終補綴装置装着 1 年後の経過観察の際に, 使用 


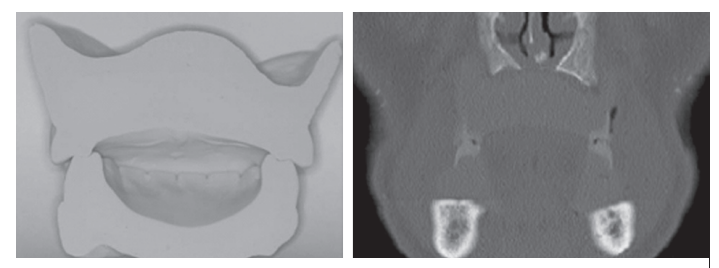

第 1 小臼歯部

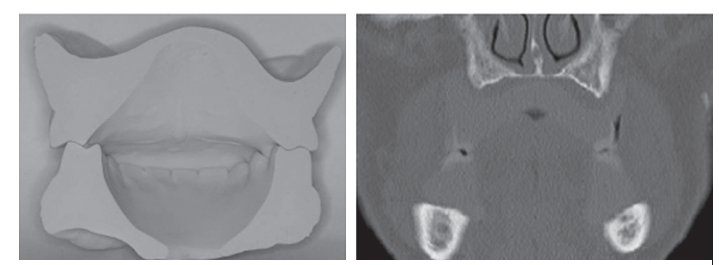

第 2 小臼歯部

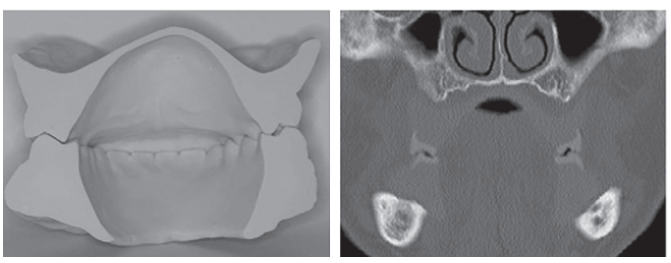

第 1 大臼歯部

図 9 A dupe model of the final prosthesis and a frontal CT image

Part of first premolar

Part of second premolar

Part of first molar

最終補経装置のデュープ模型と CT 画像の前頭断

第 1 小臼歯部

第 2 小臼歯部

第 1 大兒歯部

している義歯でゴシックアーチ描記，静的パラトグラ ムを再度行った。 ゴシックアーチは，義歯製作時より も運動量が多くなった。 また, 使用中の義歯の中心 咬合位および偏心運動時の咬合接触は均等であった にもかかわらず, 人工歯の右側臼歯部咬合面に着色 が認められたことから, 習慣性咀嚼側が左側になっ たことが伺えた。 ラ音の義歯口蓋側研磨面への舌の接 触状態は, 義歯作製時よりも, やや前方に認められた.

現在は 3 力月おきに経過観察を行い, 義歯の適合 状態および咬合状態等の確認し, 良好な経過を得て いる.

\section{IV. 考察}

今回の症例において, 顎位を改善する際に発音障 害の状態の変化が認められた。治療用義歯により維 持・安定が得られたことで, 初診時に認められた発 音時の義歯の離脱はなくなり, これによる発音障害は ほほ解消されたが，ラ音の発音は不明瞭となった。 これは, 顎位の改善後の舌房形態の変化に対して舌 運動が順応できず，口蓋への舌の接触不良によるもの と考えられた。したがって，発音を明確にするために， 新義歯の口蓋前方部に厚みを与えた形態になった. 1 年後の経過観察時には, 新義歯装着時よりもラ音 の舌の接触がやや前方に認められた。 これは, 患者 が新義歯の口腔環境に順応し舌の運動範囲が拡大し たことが推測される。

\section{V. 結 論}

維持・安定が図られ, 発音機能が回復した新義歯は, 機能時に離脱を認めず，発音が明瞭となった，治療 前後の評価より発音, 咀嚼機能の改善が認められ, 患 者満足度も, 治療前と比較して高い評価が得られた。

\section{文献}

1) Kapur KK. A clinical evaluation of denture adhesives. J Prosthet Dent 1967; 18: 550-558.

2) Christopher DL, Richard M. The face scale: a brief. nonverbal method for assessing patient mood. Arthritis Rheum 1986; 29.

著者連絡先：小平 順可

于 261-8502 千葉市美浜区真砂 1-2-2

TEL : 043-270-3933

FAX : 043-270-3935

E-mail : ykodaira@tdc.ac.jp 